\title{
Valsts policijas pārvaldes sistēmas reforma
}

\author{
Dr. iur. Aleksandrs Matvejevs \\ Daugavpils Universitāte, Sociālo zinātṇu fakultāte, \\ Tiesibu katedra, Latvija \\ aleksandrsmatvejevs5@inbox.lv
}

\section{Kopsavilkums}

Šajā rakstā ir sniegts pārskats par policijas struktūru un procesu reformu veidu izmaināām demokrātijas pārejas kontekstā. Sākumā tiks apskatīts demokrātiskas policijas darbības jēdziens kā viens no policijas reformas mērḳiem, un pēc tam arī daži šşēešlı̆i un problēmas, ar kuriem nākas saskarties reformu gaitā.

Policijas pārvaldes sistēmas reformai ir būtiska nozīme, valstij pārejot uz demokrātisku pārvaldes formu. Virzībai uz demilitarizāciju un decentralizāciju ir liela nozīme policijas pārvaldes sistēmas reformas procesā.

Atslēgvārdi: reforma, demilitarizācija, decentralizācija, pārvalde.

\section{levads}

Ja tiks pieṇemti nepareizi lēmumi par Valsts policijas pārvaldes sistēmas reformu, nākotnē tie var nelabvēlīgi ietekmēt sabiedrības attīstību. Reformai ir nepieciešama uz problēmām orientēta pieeja. Tai ir jāidentificē aktuālākie problēmjautājumi, un, lai tos atrisinātu, ir nepieciešama prioritāru lēmumu pien̦emšana. Uz problēmu orientēta pieeja ir kompromiss starp divām pieejām. No vienas puses, tā ir reforma sistēmas iekšienē, un Valsts policija pati nosaka reformu saturu. No otras puses, reformas gaitā tiek ņemts vērā sabiedrības viedoklis. Uz problēmu orientētas pieejas mērḳis ir sasniegt saprotamus un taustāmus rezultātus gan attiecībā uz sabiedrības, gan uz Valsts policijas vajadzībām. Valsts policijas pārvaldes sistēmas reformu gaitā, risinot īpašas problēmas, jāizvairās no pārmērīga radikālisma, kas varētu būt nepieciešams, lai policija nonāktu pie kāda standarta vai ideāla model̦a. Kad standarts ir noteikts vai ideāls modelis izstrādāts, tad ir nepieciešami kompleksi realizācijas ieviešanas pasākumi. Šai pieejai ir divi trūkumi. Pirmais - ir nepieciešama sinhronu un saskaṇotu plaša spektra pasākumu realizēšana. Praksē visus pasākumus realizēt gandrīz nekad neizdodas. Otrais trūkums ir tas, ka 
visaptveroša reforma izraisa lielu pretestību un ir vajadzīgas vēl lielākas pūles, lai to pārvarētu. Cita pieeja ir pakāpeniskas reformas, sākot no konkrētām problēmām, identificējot svarīgākās un kritiskākās no tām un uz to pamata nosakot pasākumu kopumu, kas būtu jāīsteno līdz situācijas izmaiṇām.

Jāuzsver ilgtermiṇa nepieciešamība, lai veicamās reformas būtu sekmīgas. Pārāk daudz reformu cita pēc citas var būt īstas reformas nāve, jo tās nedod sistēmai laiku, kas ir nepieciešams, lai pien,emtu pārmaiņas un realizētu ieinteresēto pušu iespējas izvērst darbību. Daudzi reformatori izmanto vai nu pārāk radikālas, vai pārāk teorētiskas pieejas, neṇemot vērā zinātniskos pētījumus un praktisko pieredzi vai noliedzot pagātnes sasniegumus. Rezultātā policijas darbinieki tiek dezorientēti un mazāk vēlas pieṇemt un iedzīvināt reformu.

Reforma ir pasākumu komplekss, nevis strukturālas dažu Valsts policijas pārvaldes sistēmas struktūrvienību izmain̦as. Jāatzīmēe ka jaunievedumi dziḷi iespaido policijas iestādes darbinieku darbību. Ja tiek veiktas izmaiņas un tās negūst policijas darbinieku atbalstu, tad jau pirmsākumā tās ir neveiksmīgas. Pārvaldes sistēmā svarīgākais un vērtīgākais resurss ir cilvēks.

Reformas ir jāveic policijas darbinieku un sabiedrības interesēs, nevis iestāžu vadītāju vēlmes dēl kaut ko reformēt.

Viens no svarīgākajiem problēmjautājumiem: uz kādiem policijas pārvaldes organizācijas principiem jābalstās? Militarizācija, vai demilitarizācija? Centralizācija vai decentralizācija? Šie pamatjautājumi ir jāizlemj likumdevējam.

Ir nepieciešams uzsākt darbu pie jauna policijas darbību regulējoša tiesību akta izstrādes, kurš aizstātu 1991. gada 4. jūnijā Augstākās padomes pieṇemto likumu "Par policiju" [4]. Šis likums ir viens no nedaudziem spēkā esošajiem tiesību aktiem, kurš pieņemts 1990. gada 4. maija Deklarācijā [1] noteiktajā pārejas periodā un kuru ir pieṇēmis pārejas perioda parlaments - Augstākā padome.

Saskaṇā ar pētỉjuma ideju un ievadā ieskicētajiem problēmjautājumiem tā mērḳis ir kopumā apskatīt dažas Valsts policijas sistēmas pārvaldes reformas tiesiskās problēmas un ieteikt to risinājumus. Pētijuma objekts ir Valsts policijas sistēmas pārvaldes reformas virzieni. Pētijuma materiāls - Valsts policijas sistēmas pārvaldes reformas tiesiskā regulējuma normas.

Pētījuma mērḳa sasniegšanai tika izmantotas vairākas zinātniskās pētniecības metodes: vēsturiskā interpretācijas metode, lai noskaidrotu policijas darbības regulējošo tiesību normu jēgu, n,emot vērā apstākḷus, uz kuriem pamatojoties tā radìta; induktīvã un deduktīvā metode, izdarot slēdzienus par Valsts policijas sistēmas reformas svarīgākajiem virzieniem. Pētījuma teorētiskais pamats galvenokārt ir starptautiskie dokumenti un nacionālie tiesību akti, kuri regulē policijas darbību. 


\section{Policijas demilitarizācija}

Likums "Par policiju" [4] ir viens no nedaudziem spēkā esošajiem nacionālajiem tiesību aktiem, ko 1990. gada 4. maija Deklarācijā [1] noteiktajā pārejas periodā pieñēmis pārejas perioda parlaments - Augstākā Padome - un kurš veidots atbilstoši tā vēsturiskā perioda prasībām un teorētiskajām atziṇām.

Dr. iur. Z. Indrikovs norāda, ka likuma par "Par policiju” pieṇemšanas laikā

1) Latvija oficiāli vēl bija PSRS sastāvā;

2) Latvijā atradās PSRS Iekšlietu ministrijas milicijas vienības - Baltijas Transporta policijas pārvalde, 50. milicijas nodaḷa Skrundā un Iekšējā karaspēka Viḷnas divīzijai pakḷautā Milicijas sevišḳo uzdevumu vienība (OMON) un milicijas pulks (5459. karaspēka dal̦a);

3) pēc vietējo padomju pašiniciatīvas (bez tiesiskā regulējuma) daudzās pilsētās sāka veidoties pašvaldības policija;

4) Latvijas milicija atradās Iekšlietu ministrijas un republikas pilsētu un rajonu izpildkomiteju pakḷautībā (dubultā pakḷautībā);

5) visu Latvijas milicijas tehnisko apgādi centralizēti veica PSRS Iekšlietu ministrija.

Latvijas Republikas policija tika veidota kā apbruṇota un militarizēta valsts organizācija, tās darbiniekiem tika noteiktas speciālās dienesta pakāpes (1. pants, 2. panta pirmā daḷa), un savas kompetences ietvaros viṇi pārstāvēja valsts varu (2. panta trešā daḷa). Tajā laikā apbruṇota un militarizèta policija Latvijas valstij bija nepieciešama, lai to aizsargātu, - nekādu citu militāru vai militarizētu struktūru Latvijas Republikas rīcībā nebija, tādas arī nebija iespējams izveidot, jo to nepiel̦autu PSRS, pārtraucot tādu mēǵinājumu ar spēka izmantošanu. Vienīgā legālā iespēja veidot institūciju, kura būtu apbruņota, varēja būt nacionālā policija, jo to varēja apbruṇot ar vieglajiem strēlnieku ieročiem un munīciju, ko piẹ̦āva arī PSRS tiesību akti. Militarizēta policija bija nepieciešama, lai tai nepieciešamības gadījumā varētu noteikt kazarmas režìmu, brīvi pārvietot to visas Latvijas valsts teritorijā nepieciešamo dienesta uzdevumu veikšanai, pārvietot policijas darbiniekus no vienas policijas iestādes citā arī bez darbinieku piekrišanas [3, 13-14].

Eiropas Padomes Parlamentārās asamblejas 1979. gada 8. maija 690. rezolūcijas "Par Deklarāciju par policiju" sadaḷā "C. Karš un citi ārkārtas gadījumi - ārvalsts veikta okupācija" ir noteikts, ka policijas darbinieks turpina veikt savus darba pienākumus, aizsargājot cilvēkus un ìpašumu kara un ienaidnieka okupācijas gadījumā, ievērojot civiliedzīvotāju intereses. Lìdz ar to viņš nav uzskatāms par militārpersonu 1949. gada 12. augusta Trešās Ženēvas konvencijas izpratnē un noteikumi par apiešanos ar kara gūstekṇiem attiecībā uz vinu netiek piemēroti. Attiecībā uz policiju tiek piemēroti 1949. gada 12. augusta Ceturtās Ženēvas konvencijas noteikumi par civiliedzīvotāju aizsardzību kara laikā. Okupācijas vara nedrīkst uzdot policijas darbiniekiem veikt citus pienākumus nekā tos, kas minēti iepriekš. Okupācijas laikā policijas darbinieks nepiedalās pasākumos, kas vērsti pret pretošanās kustības dalībniekiem un virzīti uz sabiedrības nodarbināšanu militāros nolūkos, un militāru objektu apsargāšanā $[7,84-90]$. 
Kaut gan Latvijā ir izveidoti profesionāli Nacionālie bruṇotie spēki, likumdevējs nav skaidrojis, kā jāizpaužas Valsts policijai kā militarizētai institūcijai. Šo skaidrojumu nevar rast ne tikai likumā "Par policiju", bet arī Iekšlietu ministrijas sistēmas iestāžu un Ieslodzijuma vietu pārvaldes amatpersonu ar speciālajām dienesta pakāpēm dienesta gaitas likumā un Iekšlietu ministrijas sistēmas iestāžu un Ieslodzỉjuma vietu pārvaldes amatpersonu ar speciālajām dienesta pakāpēm disciplināratbildības likumā. Vienīgā pazīme, kura Valsts policijas darbiniekus saista ar militārām struktūrām, ir speciālās (militārās) dienesta pakāpes, kuru citās Eiropas Savienības valstīs vairs nav [3, 13-14]. Personāla politika un dienesta gaita (karjera) ir saistīta ar amatpersonu speciālajām (militārajām) dienesta pakāpēm, nevis vadoties pēc amatam atbilstošas profesionālās izglìîibas.

Likums "Par policiju," izpildot savu vēsturisko misiju, ir izsmēlis sevi, un iespēju iekḷaut tajā arvien jaunus un jaunus grozijumus un papildinājumus nav lietderīgi. Bez šaubām, šis likums vairs neatbilst mūsdienu prasībām. Pats būtiskākais šĩ tiesību akta trūkums ir tas, ka līdz šim brīdim policija ir militarizèta valsts institūcija. Virzībai uz demilitarizāciju bija liela nozīme policijas sistēmas reformas procesā, kas bijušā Padomju bloka valstīs sākās pagājušā gadsimta 90. gados. Latvijā šis process sastāv no daudziem sarežg̀itiem elementiem.

Valsts policijā ir saglabātas speciālās dienesta (militārās) pakāpes, kuras neliecina nedz par policijas darbinieka profesionālo kvalifikāciju, nedz ieṇemamo amatu. 1997. gada oktobra Eiropas Komisijas ziñojumā "Pārskats par Latvijas policijas organizatorisko un apmācību vajadzību analīzi” tika norādìts, ka tie Eiropas valstu policijas dienesti, kuri veidojušies uz militāru struktūru bāzes, visu laiku cenšas mainīt savu tēlu un attieksmi pret pakalpojumu sniegšanu sabiedrībai. Šì procesa gaitā agrākās militārās pakāpes tiek pārdēvētas un nosauktas vārdos, kas vairāk piemēroti organizācijai, kura sniedz pakalpojumus. Tika ieteikts Latvijas varas iestādēm izlemt, vai militārās pakāpes ir piemērotas šim tēlam, kā arī pārskatīt pastāvošo pakāpju struktūru un apsvērt, vai nebūtu piemērotāk nomainīt dienesta pakāpju nosaukumus uz tādiem, kuri atbilst iestādei, kura sniedz pakalpojumus sabiedrībai $[6,19]$.

Apkopotā Eiropas valstu teorētiskā un praktiskā pieredze pierāda, ka policijas darbība ir efektīvāka tajās valstīs, kurās policija ir demilitarizēta un decentralizēta.

\section{Policijas pārvaldes sistēmas decentralizācija}

Ir nepieciešama policijas pārvaldes sistēmas decentralizācija, kā arī tās darbības kontrole, kas palielina iespējas sasniegt labākus darbības rezultātus, lai nodrošinātu sabiedrībai sniegto pakalpojumu personalizāciju. Valstī nav sakārtota Valsts policijas pārvaldes sistēma, ir pārāk daudz vadỉbas līmeṇu, kas bremzē efektīvu policijas struktūrvienību vadību.

Saprotams, ka Valsts policijas darba organizāciju būtiski skāra un skars valsts administratīvi teritoriālā reforma. Saskaṇā ar 2003. gada 25. marta Ministru kabineta noteikumiem Nr. 133 "Noteikumi par plānošanas reǵionu teritorijām” tika noteikti pieci 
plānošanas reǵioni, tādēl arī Valsts policijā tika izveidotas piecas reǵionālās pārvaldes. Regiionu pārvalžu izveidošana tika uzsākta 2008. gadā, kad saskaṇā ar Valsts policijas 2007. gada 23. novembra pavēli Nr. 1736 "Par Valsts policijas struktūrvienību reorganizāciju" ar 2008. gada 1. janvāri Rīgas pilsētas Galvenās policijas pārvaldei tika pievienota Rìgas rajona policijas pārvalde. Uz šīs pārvaldes bāzes 2008. gada 1. aprīlī izveidota Rìgas regiiona pārvalde. Lai realizētu regionālo reformu Valsts policijā, no 2009. gada 1. septembra darbu uzsāka piecas Valsts policijas reǵionālās pārvaldes.

Latvijas valsts nacionālās neatkarības atjaunošanas periodā pieñemtajā likumā "Par policiju" [4] preambulā tika nostiprināts, ka ".. likums nosaka policijas .. vietu valsts pārvaldes un pašvaldības iestāžu sistēmā”. Likums noteica, ka Latvijā tiek veidota Latvijas Republikas policija kā valsts policija (preambula, 1. un 15. pants), kura iekḷauta Iekšlietu ministrijas sistēmā. Ar vēlākiem likuma "Par policiju" grozījumiem, citu tiesību aktu pieņemšanu tika izveidotas daudzas institūcijas, kuras veic policijas funkcijas valstī. Šobrīd valstī kopumā ir 11 operatīvās darbības subjekti un 11 izmeklēšanas iestādes. Administratīvā pārkāpuma procesu ir tiesīgas veikt amatpersonas no 50 publisko personu iestādēm.

2006. gada 15. jūnijā [2] no likuma "Par policiju" tika izslēgtas normas par policijas struktūru un kompetenci (17., 18. un 20. pants.). Grozijumu nepieciešamība tika pamatota ar to, ka Valsts policijas struktūra saskaṇā ar Valsts pārvaldes iekārtas likumu tiek atspoguḷota iestādes nolikumā un reglamentā. Iepriekšèjā redakcijā 17. pants noteica kārtības policijas struktūru un funkcijas un 18. pants - kriminālpolicijas struktūru un funkcijas. Kārtỉbas policija tika veidota pēc administratīvo teritoriju dalījuma principa, savukārt kriminālpolicija - pēc reǵionālā principa. Likuma 20. pants noteica Policijas departamenta un tam paḳ̦auto apakšvienību kompetenci un to, ka policijas iecirknis ir Latvijas Republikas valsts policijas sistēmas pamatvienība.

Valsts policijas nolikumā [9] ir noteikts, ka Valsts policiju vada Valsts policijas priekšnieks. Viṇš veic valsts pārvaldes iekārtas likumā noteiktās tiešās pārvaldes iestādes vadītāja funkcijas. Valsts policijas struktūru un darba organizāciju nosaka Valsts policijas reglamentā. Ministru kabineta izdotais Valsts policijas nolikums ir ārējais normatīvais akts, savukārt Valsts policijas reglaments - iekšējais normatīvais akts. Valsts pārvaldes iekārtas likuma [10] 72. panta ceturtajā daḷā noteikts, ka iekšejjais normatīvais akts ir saistošs iestādei (tās struktūrvienībai, darbiniekiem) vai amatpersonām, attiecībā uz kurām tas izdots.

No likuma "Par policiju" nepamatoti tika svītrots 17., 18. un 20. pants, kuri noteica policijas struktūru un kompetenci. Iekšējais normatīvais akts (reglaments) nevar aizskart trešās personas intereses, jo ir saistošs iestādei (tās struktūrvienībai, darbiniekiem) vai amatpersonām, attiecībā uz kurām tas izdots.

Valsts policija valsts pārvaldes sistēmā ir patstāvīga institūcijas grupa, kura veic uzraudzības, kontroles un piespiešanas funkcijas. Policijas darbiniekam ir pieškirtas pilnvaras valsts pārvaldē attiecībā uz personām, kuras neatrodas viṇa pakḷautībā. Jāṇem vērā tas, ka Valsts policija realizē administratīvās, kriminālprocesuālās un operatīvās 
darbības. Tikai padomju valsts pārvaldes sistēmā šāda norobežošana tika aizvietota ar vienotu jēdzienu "valsts pārvaldes institūcijas", kas saglabājies arī mūsdienu zinātnieku darbos $[5,143-144]$.

\section{Lietuvas policijas darbības tiesiskais regulējums}

Salīdzinot Latvijas Republikas un Lietuvas Republikas likumus, var konstatēt to, ka Lietuvas Republikā 2000. gada 17. oktobrī ir pieñemts Policijas darbības likums [11]. Lietuvas Republikas policija ir institūciju un policijas darbinieku kopums, kas nodrošina sabiedrības drošibu un sabiedrisko kārtību (2. panta pirmais apakšpunkts). Policijas institūcija ir Policijas darbības likuma un citu likumu noteiktajā kārtībā nodibināta juridiska persona, kura veic policijas uzdevumus, kas tai noteikti ar likumiem un citiem tiesību aktiem (2. panta otrais apakšpunkts). Policijas darbinieks ir Lietuvas Republikas pilsonis, kas ir pieņemts policijas iestādē kā ierēdnis, un tam ir piešḳirtas pilnvaras valsts pārvaldē attiecībā uz personām, kuras neatrodas viṇa pakḷautībā (2. panta trešais apakšpunkts).

Policijas darbības likuma 7. pants noteic Iekšlietu ministra kompetenci. Tiesību akta 11. nodal̦ā ir noteikta Lietuvas policijas sistēma, savukārt 13. nodaḷā - policijas pārvaldes struktūra.

\section{Secinājumi un priekšlikumi}

1. Demokrātiska un uz sabiedrību orientēta policija tiek organizēta kā pakalpojuma sniedzēja institūcija. Šobrīd likumā "Par policiju" noteikts, ka policija ir apbrun,ota militarizēta valsts institūcija, kas ir pretrunā uz pakalpojuma sniegšanu orientētai policijai.

2. Policijas pārvaldes sistēmas reformai ir būtiska nozīme, valstij pārejot uz demokrātisku pārvaldes formu. Virzībai uz demilitarizāciju un decentralizāciju ir liela nozīme policijas pārvaldes sistēmas jomas reformas procesā.

3. Policijas funkcijas tiek veiktas civilā sabiedrībā:

1) funkcijas tiek realizētas ar civili organizētu policiju;

2) policija ir pakḷauta civilvaras iestādei.

4. Normatīvajā aktā, kas regulē policijas darbību, ir nepieciešama precīza izpildvaras administratīvās funkcijas nodalī̌̌ana no pārējiem policijas darbības veidiem (kriminālprocesuālās un operatīvās darbības). Policija vispirms realizē izpildvaras administratīvās funkcijas.

5. Normatīvajā aktā ir jānosaka policijas darbības mērḳi. Viens no svarīgākajiem ir demokrātiskas kārtības nodrošināšana valstī.

6. Normatīvajā aktā, kas regulē policijas darbỉbu, ir jānosaka precīza policijas vadības un kontroles sistēma, ko realizē valsts un pašvaldỉbas. Bez tās policijas darbība zaudē jēgu, jo tās galvenais uzdevums - aizsargāt iedzīvotājus no tiesībpārkāpumiem - objektīvi nevar tikt realizēts ārpus to institūciju kopējās 
vadības un kontroles, kuras pauž iedzīvotāju gribu un darbojas vinu vārdā. Citādi policijas iestādes un tās struktūrvienības vienkārši pārvērtīsies noslēgtā sistēmā, kas neievēro sabiedrības intereses un tātad nav tai vajadzīga.

7. Normatīvajā aktā ir jānosaka, uz kādiem policijas pārvaldes organizācijas principiem jābalstās. Militarizācija vai demilitarizācija? Centralizācija vai decentralizācija?

8. Policijas iestāde var attīstīties, ja policija bauda sabiedrības atbalstu un sadarbojas ar to.

9. Tiesību aktiem, kas regulē policijas darbību, ir jābūt pieejamiem sabiedrībai, tiem jābūt precīziem un skaidriem, ja nepieciešams - papildinātiem ar skaidriem noteikumiem, kas arī pieejami sabiedrïbai.

10. Valsts policijas pārvaldes reforma ir ilgstošs process; svarīgi ir nodrošināt reformas tiesiskumu, tādēḷ ir jāuzsāk darbs pie jauna policijas darbỉbu regulējoša tiesību akta izstrādes.

\section{Reform of the State Police Administration System}

\section{Abstract}

The article provides an overview of changes in the way police structures and processes are reformed in the context of the democratic transition. It begins by looking at the concept of democratic policing as one of the aims of police reform, as well as some of the obstacles and challenges that it faces in the course of reform.

Reform of the police administration system is essential for the country's transition to a democratic form of government. The move towards demilitarisation and decentralisation is important in the process of reforming the police administration.

Keywords: reform, demilitarisation, decentralisation, governance.

\section{Avoti un literatūra}

1. Deklarācija "Par Latvijas Republikas neatkarības atjaunošanu." Latvijas Republikas Augstākās Padomes un Valdības Ziñotājs. 17.05.1990. (pamatredakcija). Stājies spēkā 17.05.1990. Iegūts no: https://likumi.lv/ta/id/75539-par-latvijas-republikas-neatkaribas-atjaunosanu [sk. 15.03.2020.].

2. Grozijumi likumā "Par policiju". 13.05.2006. likums. Latvijas Vēstnesis. 98(3466), 27.06.2006. Stājās spēkā 01.10.2006.

3. Indrikovs, Z. 2007. Policijas jēdziens demokrātiskā valstī. Administratīvā un Kriminālāā Justìija, 3.

4. Latvijas Republikas likums "Par policiju". 04.06.1991. likums. Latvijas Republikas Augstākās Padomes un Valdības Zinnotājs, 31/32. 1991. (pamatredakcija). Stājies spēkā 04.06.1991. 
5. Matvejevs, A. 2009. Policijas darbības teorijas attīstības tendences. SIA "Pertovskis un Ko".

6. Pārskats "Par Latvijas policijas organizatorisko un mācību darbu” (Eiropas Komisijas ziṇojums). 1998. Rīga: Latvijas Policijas akadēmija, 19. lpp.

7. Rezolūcija 690 (1979) par Deklarāciju par policiju. Pieṇemta Eiropas Padomes Parlamentārajā asamblejā 1979. gada 8. maijā (31. sesija, 2. sēde). Policija un cilvēktiesības. Eiropas aktualitātes. Cilvēktiesību Žurnāls. 13-14/2000, 84.-90. lpp.

8. Tiesībsargājošās institūcijas Latvijā un Eiropā. 2019. Rīga: Juridiskā koledža.

9. Valsts policijas nolikums. 18.01.2005. noteikumi Nr. 46. Latvijas Vēstnesis. 12(3170), 21.01.2005. (pamatredakcija). Stājās spēkā 22.01.2005. Iegūts no: https://likumi.lv/doc.php?id=99940 [sk. 20.03.2020.].

10. Valsts pārvaldes iekārtas likums. 06.06.2002. likums. Latvijas Vēstnesis. 94(2669), 21.06.2002. (pamatredakcijā). Stājās spēkā 01.01.2003. Iegūts no: https://likumi.lv/doc.php?id=63545 [sk. 20.03.2020.].

11. Закон Аитовской республики от 17 октября 2000 г. № VIII-2048 “О деятельности полиции”. Iegūts no: https://e-seimas.lrs.lt/portal/legalAct/lt/TAD/TAIS.288152?jfwid=q8i88m80c [sk. 20.03.2020.]. 